\title{
В.В. Цибуленко ${ }^{1 *}$, С.В. Шутов ${ }^{1}$, О.О. Боскін ${ }^{2}$
}

${ }^{1}$ Інститут фізики напівпровідників ім. В.Є. Лашкарьова НАН України, Київ, Україна

${ }^{2}$ Херсонський національний технічний університет, Херсон, Україна

*corresponding author: v-ts@isp.kiev.ua

\section{ОСОБЛИВОСТІ ВИКОРИСТАННЯ МЕТОДУ СКАНУЮЧОЇ РІДИННОФАЗОВОЇ ЕПІТАКСІЇ ДЛЯ ВИРОЩУВАННЯ ТОВСТИХ ЕПІТАКСІЙНИХ ШАРІВ}

Проблематика. Вирощування як тонких, так і товстих епітаксійних шарів є невід'ємною частиною технології напівпровідникових приладів. До відомих технологічних методів належать методи рідиннофазової епітаксії, серед яких - імпульсні методи, розроблені спеціально для отримання саме тонких епітаксійних шарів. Пристосування або модернізація останніх для отримання ще й товстих епітаксійних шарів є актуальною задачею. Мета дослідження. Робота присвячена розширенню можливостей методу скануючої рідиннофазової епітаксії, який теж можна віднести до імпульсних методів вирощування з рідинної фази, а саме можливості вирощування товстих епітаксійних шарів.

Методика реалізації. Розглянуто вплив додаткового підігріву підкладки в методі скануючої рідиннофазової епітаксії на ріст епітаксійних шарів. Для цього проведено моделювання процесів тепло- та масопереносу в установці скануючої рідиннофазової епітаксії в умовах додаткового підігріву підкладки. Для експериментального підтвердження працездатності запропонованої моделі було проведено вирощування епітаксійного шару Ge на підкладці GaAs у зазначених умовах.

Результати дослідження. Моделювання показало, що якщо підкладка контактує з розчином-розплавом більше 1 с в умовах додаткового підігріву підкладки в методі скануючої рідиннофазової епітаксії, то на графіку залежності товщини вирощеного епітаксійного шару від часу вирощування з'являється ділянка розчинення епітаксійного шару. При цьому температура на фронті кристалізації менша за початкову температуру розчинурозплаву. Показано, що це пов’язано з величиною початкового охолодження/нагріву нагрівача підкладки. Також моделювання показало, що завдяки додатковому підігріву підкладки ріст епітаксійного шару відбувається мовби в градієнті температури. Причому вже за лічені секунди відбувається ріст у сталому в часі градієнті температури. 3 використанням додаткового підігріву підкладки отримано епітаксійний шар Ge на підкладці $\mathrm{GaAs} 3 \mathrm{Ga}-\mathrm{Ge}-$ розчину-розплаву. Час вирощування становив 60 с. Методом шар-шліфу визначено товщину шару, яка становила 12,6 мкм.

Висновки. Показано, шо за допомогою додаткового підігріву підкладки з ії тильної сторони, за умови, що підкладка буде мати температуру нижче температури розчину-розплаву, створюються умови для вирощування товстих епітаксійних шарів у методі скануючої рідиннофазової епітаксії. При цьому ріст товстих епітаксійних шарів відбувається в умовах градієнта температури на фронті кристалізації.

Ключові слова: скануюча рідиннофазова епітаксія; сила Ампера; ріст у градієнті температури.

\section{Ветуп}

У технології напівпровідникових приладів виникає необхідність у вирощуванні не тільки тонких, але й товстих епітаксійних шарів, до того ж іноді в одному технологічному процесі.

Одним із різновидів рідиннофазової епітакciï, що дає змогу отримувати тонкі й надтонкі епітаксійні шари, є метод скануючої рідиннофазової епітаксії. Цей метод докладно описаний у працях [1-3]. При короткочасному контакті підкладки з розчином-розплавом, що використовується в методі скануючої рідиннофазової епітаксії, товстих епітаксійних шарів не виростити. Це пов'язано з обмеженнями в швидкості росту. Щоб виростити більш товстий епітаксійний шар за той самий проміжок часу, необхідно забезпе- чити більше переохолодження розчину-розплаву, тобто збільшити швидкість росту. За великої величини переохолодження розчину-розплаву виникає концентраційне переохолодження, яке і зриває ріст епітаксійного шару. В результаті відбувається ріст кристалів у самому розчині-розплаві. Тому для вирощування більш товстих епітаксійних шарів необхідне створення умов для більш тривалого контакту підкладки 3 розчином-розплавом за помірних градієнтів температури між підкладкою і розчином-розплавом.

\section{Постановка задачі}

Мета роботи - показати можливість створення умов для отримання товстих епітаксійних шарів методом скануючої рідиннофазової епі- 
таксії. Це зроблено на прикладі вирощування епітаксійних шарів $\mathrm{Ge}$ на підкладці GaAs iз GaGe-розчину-розплаву.

\section{Теорія}

Для розгляду нами була вибрана система $\mathrm{Ge} / \mathrm{GaAs}$ через іiі ізоперіодність і достатньо велику розчинність $\mathrm{Ge}$ у $\mathrm{Ga}$ [4]. Для створення умов отримання товстих епітаксійних шарів у методі скануючої рідиннофазової епітаксії нами пропонується використання додаткового підігріву підкладки. Реалізувати це ми пропонуємо за рахунок використання нагрівача підкладки для установки скануючої рідиннофазової епітаксії. Цей нагрівач має ставитись на тильну сторону підкладки і повинен мати температуру нижче температури розчину-розплаву.

Для перевірки працездатності запропонованої ідеї нами був зроблений розрахунок технологічних режимів методу скануючої рідиннофазової епітаксії. Зокрема, було знайдено мінімально можливу температуру охолодженої підкладки при контакті з нагрітим розчином-розплавом. При такому контакті формуються механічні напруження [5, 6], які можуть призвести до руйнування підкладки. Розрахунок, зроблений нами в [7], показав, що для уникнення руйнування підкладки GaAs товщиною 400 мкм iii температура має становити не менше $25^{\circ} \mathrm{C}$ за температури $\mathrm{Ga}-\mathrm{Ge}-$ розчину-розплаву $500^{\circ} \mathrm{C}$.

У методі скануючої рідиннофазової епітаксії використовується спосіб змочування підкладки та її очищення від розчину-розплаву за допомогою сили Ампера. Тому для етапів змочування підкладки і ії очищення від розчину-розплаву необхідно знати, наприклад, значення загального струму крізь розчин-розплав при заданому магнітному полі. Ці значення знайдені дослідним шляхом. Вони становили відповідно для змочування і очищення $<40 \mathrm{i}>40$ А при градієнтному розподіленні напруженості магнітного поля по висоті розчину-розплаву від 200 мТл на фронті кристалізації до 80 мТл у нижній його частині:

$$
B=0,8 \cdot d_{\mathrm{sm}}^{2}+11,6 \cdot d_{\mathrm{sm}}+78,1, \text { мТл }
$$

де $d_{\mathrm{sm}}$ - висота розчину-розплаву, мм.

Для вивчення процесів теплопереносу в розчині-розплаві, підкладці та нагрівачі підкладки було розв'язано типове рівняння Фур'є-Кірхгофа 3 граничними умовами I роду на верхній і нижній границях. У розрахунку теплопереносу вважалося, що джоулів нагрів та ефект Пельтьє $[8,9]$ роблять незначний вклад у зміну товщини епітаксійного шару, тому вони не були враховані:

$$
\frac{\partial T}{\partial t}=\frac{k}{\rho_{\mathrm{sm}} c_{\mathrm{p}}}\left(\frac{\partial^{2} T}{\partial x^{2}}+\frac{\partial^{2} T}{\partial y^{2}}+\frac{\partial^{2} T}{\partial z^{2}}\right),
$$

де $T$ - температура, $\mathrm{K} ; k$ - коефіцієнт теплопровідності, Дж/(см.с.К); $c_{\mathrm{p}}$ - питома теплоємність, Дж/(г·К); $t-$ час, с.

Початкові умови. В початковий момент часу вважалося, що розчин-розплав і охолоджена підкладка знаходяться за різних температур, а розподілення температури по їх товщині $є$ однорідним. Нагрівач підкладки має градієнтне початкове розподілення температури по висоті, а умови тепловідведення від його стінок відповідали вільній (природній) конвекції.

Також вважалося, що під час вирощування температура в нижній частині розчину-розплаву дорівнює іії початковій температурі, а температура верхньої границі нагрівача підкладки теж $є$ сталою і дорівнює $800^{\circ} \mathrm{C}$. Граничні умови, відповідно, мають такий вигляд:

- на верхній границі:

$$
T_{\mathrm{hs}}(0, t)=800{ }^{\circ} \mathrm{C},
$$

- на стінках нагрівача підкладки:

$$
k_{\mathrm{hs}} \frac{\partial T_{\mathrm{hs}}(n, t)}{\partial z}=a\left(T_{\mathrm{hs}}(n, t)-T_{\mathrm{hs}}(n, 0)\right),
$$

- на стінках підкладки:

$$
T_{\mathrm{S}}(n, t)=T_{\mathrm{S}}(n-1, t),
$$

- на стінках розчину-розплаву:

$$
T_{\mathrm{sm}}(n, t)=T_{\mathrm{sm}}(n-1, t),
$$

- на нижній границі:

$$
T_{\text {sm }}(0, t)=500{ }^{\circ} \mathrm{C} ;
$$

- на внутрішній границі між розчиномрозплавом і підкладкою:

$$
k_{\mathrm{s}} \frac{\partial T}{\partial z}-k_{\mathrm{sm}} \frac{\partial T}{\partial z}=0
$$

- на внутрішній границі між підкладкою і нагрівачем підкладки:

$$
k_{\mathrm{hs}} \frac{\partial T}{\partial z}-k_{\mathrm{s}} \frac{\partial T}{\partial z}=0
$$

де $n$ означає по нормалі до поверхні. 
Коефіцієнт тепловіддачі $\alpha$, для охолоджуваної ділянки нагрівача підкладки за умови вільної (природної) конвекції, знаходився за формулою

$$
\begin{gathered}
a=\frac{N u \cdot k_{\mathrm{g}}}{l_{\mathrm{hs}}}= \\
=1,18\left(\frac{g \cdot \beta \cdot\left(T_{\mathrm{hs}}(z, t)-T_{\mathrm{hs}}(z, 0)\right) \cdot l_{b}^{3}}{v_{\mathrm{g}}^{2}} \frac{v_{\mathrm{g}}}{a_{T, \mathrm{~g}}}\right)^{0,125} \times \\
\times\left(\frac{v_{\mathrm{g}} / \alpha_{T, \mathrm{~g}}}{v_{\mathrm{hs}} / \alpha_{T, \mathrm{hs}}}\right)^{0,25} \frac{k_{\mathrm{g}}}{l_{\mathrm{hs}}}
\end{gathered}
$$

де $N u$ - число Нуссельта; $g$ - прискорення вільного падіння, м/ $\mathrm{c}^{2} ; \beta-$ коефіцієнт об'ємного розширення газу, $1 / \mathrm{K} ; l_{\mathrm{hs}}-$ висота охолоджуваної ділянки нагрівача підкладки, см; $v=\eta / \rho-$ коефіцієнт кінематичної в'язкості, $\mathrm{cm}^{2} / \mathrm{c} ; \eta$ коефіцієнт динамічної в'язкості, Н·с $/ \mathrm{cm}^{2} ; \alpha_{T}=$ $=k /\left(\rho \cdot c_{p}\right)-$ коефіцієнт температуропровідності, $\mathrm{cm}^{2} / \mathrm{c}$; індекси "g" i "hs" позначають для газу i поверхні нагрівача підкладки відповідно.

Розв'язавши рівняння (1) з початковими та граничними умовами (2)-(4), знаходимо температуру на фронті кристалізації.

Розрахунок масопереносу виконано за [10]. При цьому електроперенос [8], який виникає в розчині-розплаві, не враховувався через малу рухливість $\mathrm{Ge}$ у $\mathrm{Ga}[11]$ і малий час етапів змочування й очищення.

У розрахунках були використані такі значення і залежності:

- залежність коефіцієнта лінійного розширення GaAs від температури з [12];

- залежність коефіцієнтів пружності GaAs від температури з [13];

- залежності густини галію $\rho$ Ga, германію $\rho$ Ge Ta підкладки $\rho$ GaAs від температури, взяті з [10, 14]. При цьому густина розчину-розплаву $\rho_{\mathrm{sm}}$ знаходилася за формулою $\rho_{\mathrm{sm}}=\rho_{\mathrm{Ga}}(1-x)+\rho_{\mathrm{Ge}} x$;

- залежність питомої теплоємності від температури з [10].

Результати розрахунків наведені на рис. 1.

На відміну від короткочасного контакту (близько $1 \mathrm{c}$ ), при більш довготривалому контакті (більше 1 с) у методі скануючої рідиннофазової епітаксії на картині росту з'являється ділянка від'ємного росту, тобто ділянка розчинення епітаксійного шару (див. рис. $1, a$ ). Це при тому, що температура на фронті кристалізації менша за початкову температуру розчинурозплаву. Тобто є переохолодження розчину- розплаву. На нашу думку, це пов'язано з початковими умовами. Холодний кінець нагрівача підкладки приводиться у контакт з тильною стороною підкладки. Спочатку розчин-розплав охолоджується на певну глибину, а потім - прогрівається. За певних умов, як у випадку на рис. $1, a$, початкове охолодження розчину розплаву $є$ надто великим, через що подальший нагрів розчинурозплаву призводить до розчинення, а потім знову до росту епітаксійного шару. Для порівняння нами був зроблений розрахунок для умов, коли температура робочої поверхні підкладки на момент контакту становила б на $100{ }^{\circ} \mathrm{C}$ більше (див. рис. 1, б). Видно, що ділянка розчинення зникає. Таким чином, наявність ділянки розчинення пов'язана 3 величиною початкового охолодження (нагріву) нагрівача підкладки.
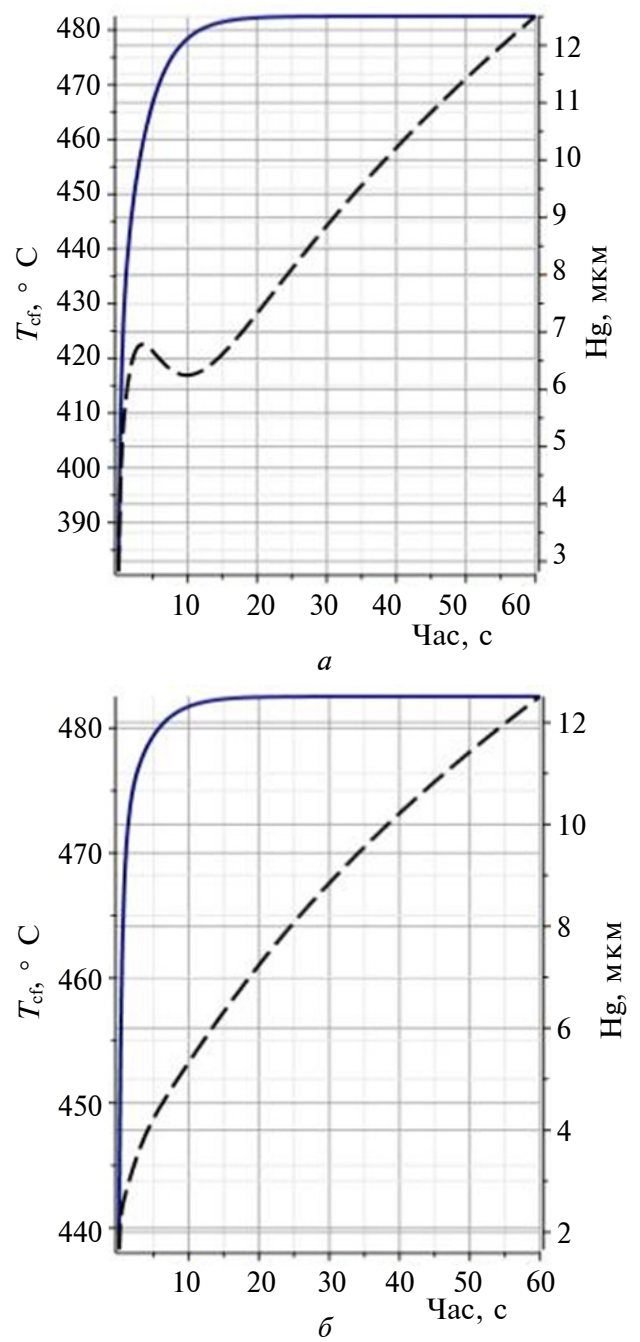

Рис. 1. Залежність температури на фронті кристалізації та товщини шару від часу за температури робочої поверхні підкладки на момент контакту: $a-270{ }^{\circ} \mathrm{C}$; $\sigma-$ $370^{\circ} \mathrm{C} ;--T_{\mathrm{cf}} ;---\mathrm{Hg}$ 
Важливо, що з рис. 1 видно, що завдяки додатковому нагрівачу підкладки ріст епітаксійного шару відбувається мовби в градієнті температури. Фронт кристалізації стає холоднішим за початкову температуру розчину-розплаву на певну величину миттєво. Причому вже за $~ 15$ с росту температура на фронті кристалізації стає сталою і меншою за початкову температуру розчину-розплаву. Тобто ріст відбувається вже у сталому в часі градієнті температури.

Тримати підкладку в такому стані можна доти, доки пересичення розчину-розплаву не буде знято. Обмежувати цей процес будуть тільки коефіцієнт взаємодифузії компонентів у розчині-розплаві за даної температури та розміри самого розчину-розплаву уздовж напрямку градієнта температури. Для ростової комірки (рис. 2, 3 у розділі "Експеримент") з ростовим капіляром (рис. 3) висотою 0,7 см за типового значення коефіцієнта взаємодифузії $\sim 5 \cdot 10^{-5} \mathrm{~cm}^{2} / \mathrm{c}$ характеристичний час дифузії [10] становитиме 2,7 год.

Отже, завдяки додатковому підігріву підкладки з їі тильної сторони можна створити умови для вирощування товстих епітаксійних шарів у методі скануючої рідиннофазової епітаксії. Очевидно, що керуючи параметрами нагрівача підкладки на початку процесу вирощування та/або під час вирощування, можна керувати зміною температури на фронті кристалізації.

\section{Експеримент}

Для перевірки результатів моделювання нами був проведений експеримент із вирощування епітаксійного шару Ge на підкладці GaAs $3 \mathrm{Ga}-\mathrm{Ge}-$ розчину-розплаву. Вирощування було проведено на експериментальній установці для скануючої рідиннофазової епітаксії (рис. 2) 3 розробленим і виготовленим додатковим нагрівачем підкладки для ростової комірки (рис. 3).

Для етапів змочування підкладки та ії очищення від розчину-розплаву був використаний формувач імпульсів, який дав змогу створювати імпульси струму в протилежних напрямках і керувати їх тривалістю від 0,1 до 0,3 с. Також формувач імпульсів давав можливість керувати величиною імпульсів у кожному напрямку від 5 до $120 \mathrm{~A}$.

Магнітопровід був виготовлений із заліза, магніти - зі сплаву неодим-залізо-бор ( $\mathrm{NdFeB})$ із намагніченістю N42.

Контроль температури здійснювався за допомогою термопари.

Ростова комірка для скануючої рідиннофазової епітаксії (див. рис. 3) мала розміри контейнера для гомогенізації $\varnothing 10 \times 15$ мм, ростовий капіляр $-4 \times 4 \times 7$ мм. Електроди були виготовлені 3 Ti.

Нагрівач підкладки мав розміри $4 \times 4 \times 15$ мм (не покрита нагрівачем частина під час вирощу-

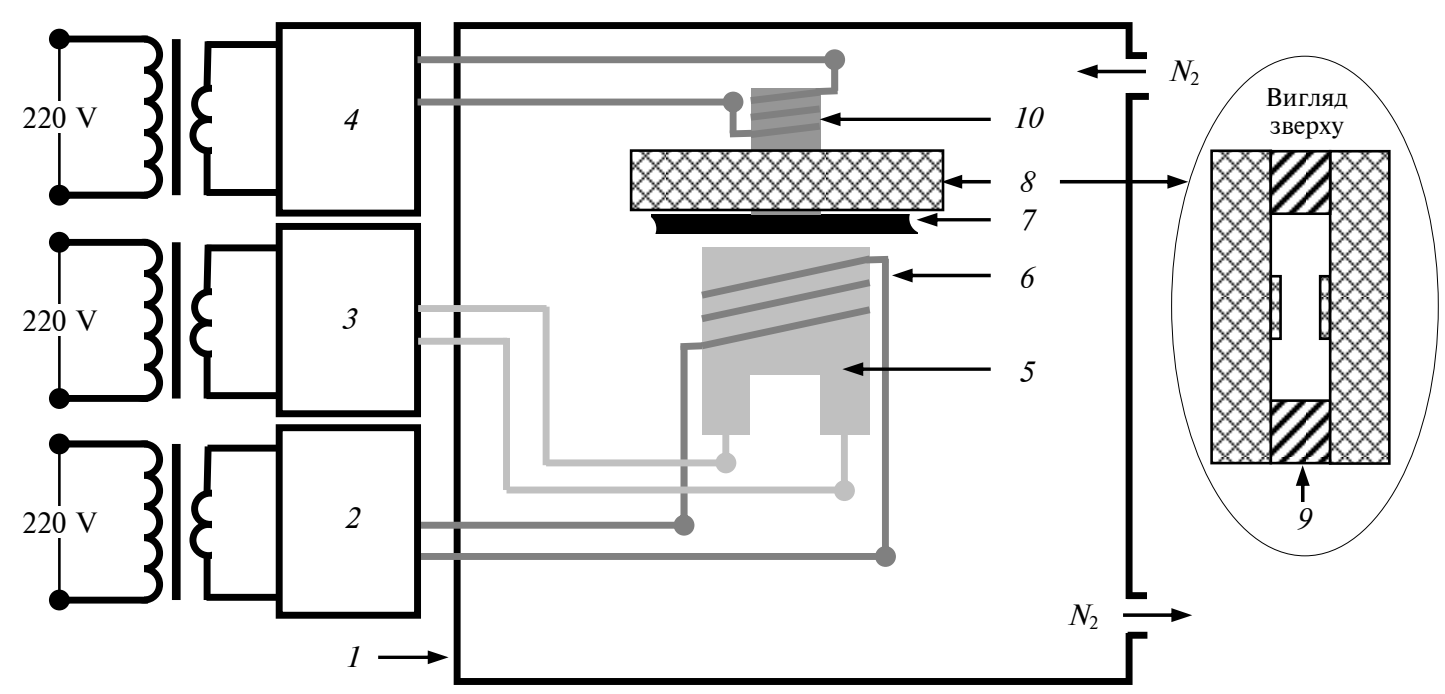

Рис. 2. Установка для скануючої рідиннофазової епітаксії: 1 - газова камера; 2 - блок керування нагрівальним вузлом; 3 - формувач імпульсів; 4 - блок керування підігрівачем підкладки; 5 - ростова комірка; 6 - нагрівач; 7 - підкладка; 8 - магнітопровід; 9 - магніти; 10 - підігрівач підкладки 


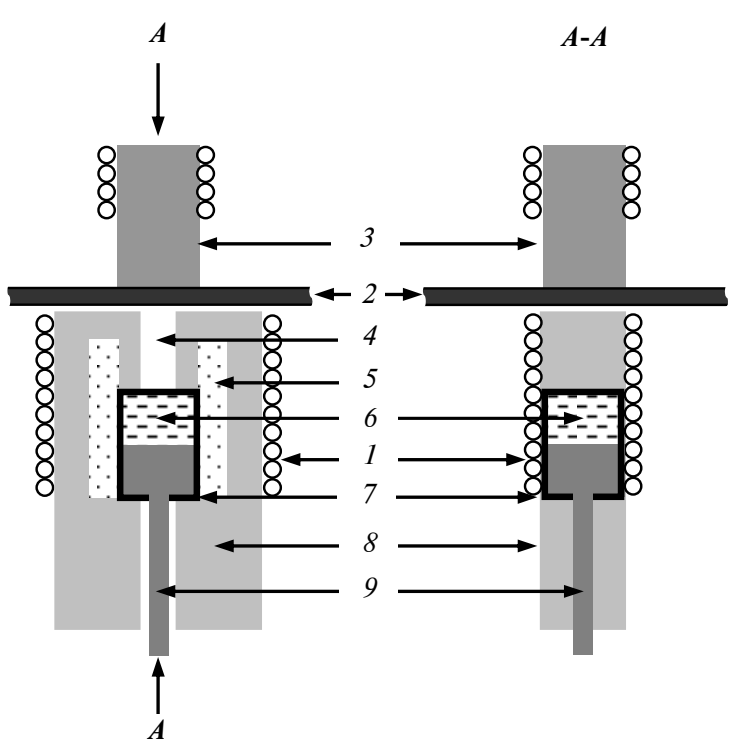

Рис. 3. Ростова комірка установки для скануючої рідиннофазової епітаксії: 1 - нагрівач; 2 - підкладка; 3 - підігрівач підкладки; 4 - ростовий капіляр; 5 - високотемпературний ізолятор (кераміка); 6 розчин-розплав; 7 - контейнер для гомогенізації; 8 - електрод; 9 - поршень

вання) і був виготовлений із нержавкої сталі для уникнення викривлення магнітного поля.

Підготовка. Навіски масою $\sim 1$ г були виготовлені окремо у вигляді суцільної твердої таблетки, в якій уже попередньо проведена гомогенізація. Підкладка GaAs має орієнтацію (111) $\mathrm{n} \sim 10^{18} \mathrm{~cm}^{-3}$. Зняття верхнього, механічно порушеного, шару проводилося хімічним травленням підкладки в $\mathrm{H}_{2} \mathrm{SO}_{4}: \mathrm{H}_{2} \mathrm{O}_{2}: \mathrm{H}_{2} \mathrm{O}=5: 0.5: 1$ упродовж 15 хв за температури $25^{\circ} \mathrm{C}$.

Проведення. Після компоновки комірки й установки була здійснена продувка камери інертним газом - азотом. Потім був проведений процес вирощування епітаксійного шару за методикою, описаною в [1]. Початкові температури розчину-розплаву і робочої поверхні підкладки на момент контакту становили 500 і $270{ }^{\circ} \mathrm{C}$ відповідно. Час додаткової гомогенізації - 30 хв. Час контакту розчину-розплаву з підкладкою 60 с. Під час цього контакту відбувався ріст епітаксійного шару Ge. Після завершення вирощування епітаксійного шару підкладка очищувалася від розчину розплаву за допомогою сили Ампера.

Після процесу вирощування на підкладці залишився тонкий шар розчину-розплаву - "залишковий” шар. На нашу думку, це сталося через невеликий кут змочування розчином-розплавом підкладки - тобто через високу адгезію розчину-розплаву до підкладки. Проте підкладка після процесу вирощування, або розриву контакту із розчином-розплавом, майже миттєво остигає до початкової температури. А отже, миттєво припиняється і ріст епітаксійного шару. Через це, на нашу думку, “залишковий” шар не вплинув на кінцеву товщину епітаксійного шару. Зняття “залишкового” шару проводилося в концентрованій соляній кислоті.

\section{Результати і обговорення}

На рис. 4, а можна побачити світлину поверхні отриманого зразка, одержану при збільшенні $\times 230$.

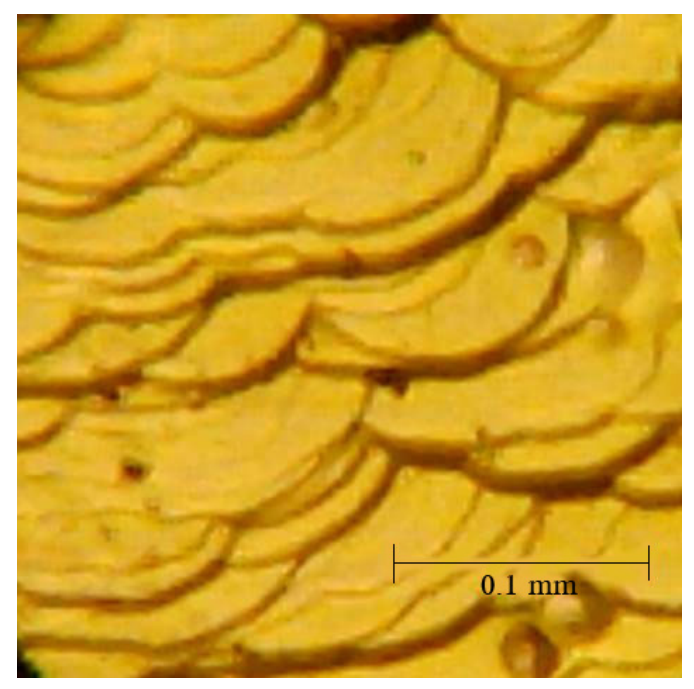

$a$

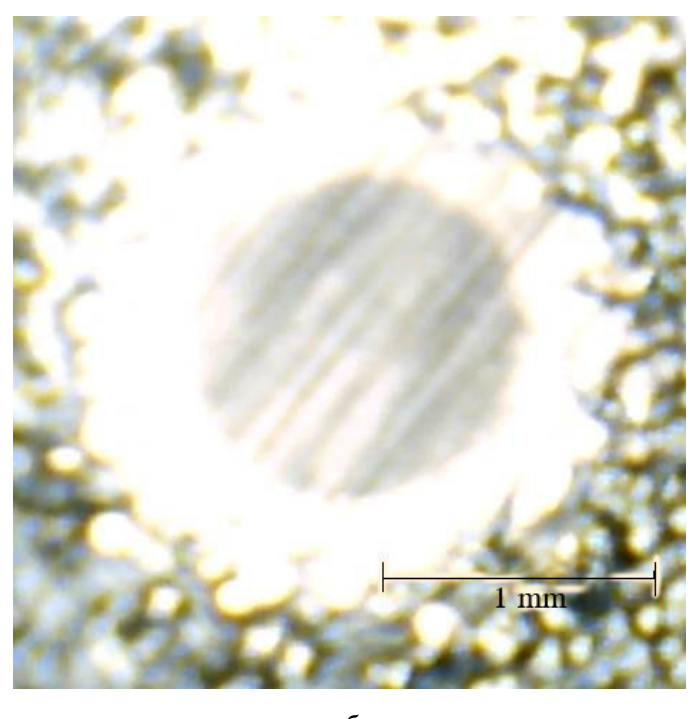

$\sigma$

Рис. 4. Світлини зразка: $a$ - поверхні епітаксійного шару; $б$ - поверхні шар-шліфу 
За великої швидкості кристалізації або великого градієнта температури на фронті кристалізації може виникнути концентраційне переохолодження розчину-розплаву через накопичення речовини біля фронту кристалізації. У такому разі спостерігається комірковий ріст шару на поверхні підкладки. У разі значного концентраційного переохолодження ріст міг взагалі припинитися. Проте на рис. 4, $a$ ми бачимо сходинки росту. Це говорить про те, що ріст епітаксійного шару був пошарово-спіральним. Тобто градієнт температури на фронті кристалізації, який ми створили, не вплинув на морфологію отриманого епітаксійного шару.

Оскільки очікувана товщина шару є достатньо великою, для ії вимірювання був використаний метод шар-шліфу. Діаметр кульки становив 51 мм. Для створення шліфу була використана алмазна паста АСМ 0.5/0 ПВМХ.

Після фотографування поверхні шар-шліфу на мікроскопі зі збільшенням $\times 40$ (див. рис. 4, б) була розрахована товщина вирощеного епітаксійного шару $\mathrm{Ge}$, яка становила 12,6 мкм. Як бачимо, отримане значення товщини епітаксійного шару збігається з теоретично розрахованим (див. рис. 1, $a$ ).

\section{Висновки}

У роботі показана можливість вирощувати товсті епітаксійні шари методом скануючої рідиннофазової епітаксії при створенні градієнта температури на фронті кристалізації за рахунок додаткового підігріву підкладки з іiі тильної сторони. Ці умови реалізовані при використанні додаткового нагрівача підкладки в установці скануючої рідиннофазової епітаксії. В умовах градієнта температури на установці скануючої рідиннофазової епітаксії вирощений епітаксійний шар $\mathrm{Ge}$ на підкладці $\mathrm{GaAs}$ з $\mathrm{Ga}-\mathrm{Ge}-$ розчину-розплаву товщиною 12,6 мкм.

Метод скануючої рідиннофазової епітаксії, як і інші різновиди рідиннофазової епітаксії, $є$ достатньо простим і дешевим методом отримання епітаксійних структур, а отже, доступним до широкого застосування. До того ж використання методів вирощування з рідинної фази дає можливість отримувати найбільш досконалі, 3 кристалографічної точки зору, шари сполук III-V i їх твердих розчинів. Саме тому актуальними $€$ подальші дослідження щодо пристосування цього методу до вимог з вирощування сучасних епітаксійних структур.

\section{References}

[1] V. Tsybulenko et al., "LPE application technique for obtaining of thin film semiconductor materials", in Proc. 1st Int. Electronic Conf. Crystals, vol. 1, May 21-31, 2018. doi: 10.3390/IECC_2018-05250

[2] V. Tsybulenko et al., "The method of epitaxial layer obtaining from the liquid phase", Ukraine patent 93097U, 2014.

[3] V. Tsybulenko et al., "The method of substrate wetting and cleaning from a solution-melt in liquid-phase epitaxy", Ukraine patent 115873 C2, 2018.

[4] N. Lyakishev, State Diagrams of Double Metal Systems. Book 2. Moscow, Russia: Mashynostroenie, 2000, pp. 593-594.

[5] M. Milvidsky and V. Osvensky, Structural Defects in Semiconductors Epitaxyal Layers. Moscow: Metallurgiya, 1985, p. 10.

[6] L. Shuvalov, Modern Crystallography IV. Physical Properties of Crystals. Berlin, Heidelberg: Springer-Verlag, 2011 , p. 66. doi: 10.1007/978-3-642-81838-7

[7] V. Tsybulenko at al., "Conditions of growing of epitaxial layers for semiconductor structures from undersaturated solutionmelt”, in XVII Int. Young Scientists' Conf. Applied Physics, Kyiv, Ukraine, May 23-27, 2017, pp. 107-108.

[8] R. Zytkiewicz et al., "Time dependent simulations of the growth of III-V crystals by the liquid phase electroepitaxy", J. Crystal Growth, vol. 318, no. 1, pp. 351-355, 2011. doi: 10.1016/j.jcrysgro.2010.10.097

[9] W. Youdelis and S. Dost, "An interpretation for high growth rates in electroepitaxial growth of GaAs under magnetic field", J. Crystal Growth, vol. 307, no. 1, pp. 203-210, 2007. doi: 10.1016/j.jcrysgro.2007.05.060

[10] I. Sokolov, Calculations of Semiconductor Technology Processes. Moscow, Russia: Metallurgiya, 1994, p. 96.

[11] V. Mihailov, Electromigration and Its Applications. Novosibirsk, SU: Nauka, 1982, pp. 68-69.

[12] V. Yang et al., "Crack formation in GaAs heteroepitaxial films on Si and SiGe virtual substrates", J. Appl. Phys, vol. 93, no. 7, p. 3861, 2003. doi: 10.1063/1.1558963

[13] GaAs - Gallium Arsenide. Mechanical properties, elastic constants, lattice vibrations [Online]. Available: http://www.ioffe.ru/SVA/NSM/Semicond/GaAs/mechanic.html

[14] V. Chentsov et al., "Density and surface tension of heavy liquid-metal coolant. Gallium and Indium”, Perspektivnye Materialy, vol. 3, pp. 46-52, 2011. doi: 10.1134/S2075113311050108 
В.В. Цыбуленко, С.В. Шутов, О.О. Боскин

\section{ОСОБЕННОСТИ ПРИМЕНЕНИЯ МОТОДА СКАНИРУЮЩЕЙ ЖИДКОФАЗНОЙ ЭПИТАКСИИ ДЛЯ ВЫРАЩИВАНИЯ ТОЛСТЫХ ЭПИТАКСИАЛЬНЫХ СЛОЕВ}

Проблематика. Выращивание как тонких, так и толстых эпитаксиальных слоев является неотъемлемой частью технологии полупроводниковых приборов. К известным технологическим методам принадлежат методы жидкофазной эпитаксии, среди которых - импульсные методы, разработанные специально для получения именно тонких эпитаксиальных слоев. Адаптация или модернизация последних для получения еще и толстых эпитаксиальных слоев является актуальной задачей.

Цель исследования. Работа посвящена расширению возможностей метода сканирующей жидкофазной эпитаксии, который тоже можно отнести к импульсным методам выращивания из жидкой фазы, а именно возможности выращивания толстых эпитаксиальных слоев.

Методика реализации. Рассмотрено влияние дополнительного подогрева подложки в методе сканирующей жидкофазной эпитаксии на рост эпитаксиальных слоев. Для этого проведено моделирование процессов тепло- и массопереноса в установке сканирующей жидкофазной эпитаксии в условиях дополнительного подогрева подложки. Для экспериментального подтверждения работоспособности предложенной модели было проведено выращивание эпитаксиального слоя Ge на подложке GaAs в указанных условиях.

Результаты исследования. Моделирование показало, что если подложка контактирует с раствором-расплавом больше 1 с в условиях дополнительного подогрева подложки в методе сканирующей жидкофазной эпитаксии, то на графике зависимости толщины выращенного эпитаксиального слоя от времени выращивания появляется отрезок растворения эпитаксиального слоя. При этом температура на фронте кристаллизации меньше начальной температуры раствора-расплава. Показано, что это связано с величиной начального охлаждения/нагрева нагревателя подложки. Также моделирование показало, что благодаря дополнительному подогреву подложки рост эпитаксиального слоя происходит как бы в градиенте температуры. Причем уже за считанные секунды происходит рост в постоянном во времени градиенте температуры. Путем применения дополнительного подогрева подложки получен эпитаксиальный слой Ge на подложке GaAs из Ga-Ge-раствора-расплава. Время выращивания составляло 60 c. Методом шар-шлифа определена толщина слоя, которая составила 12,6 мкм.

Выводы. Показано, что при помощи дополнительного подогрева подложки с ее тыльной стороны, при условии, что подложка будет иметь температуру ниже температуры раствора-расплава, создаются условия для выращивания толстых эпитаксиальных слоев в методе сканирующей жидкофазной эпитаксии. При этом рост толстых эпитаксиальных слоев происходит в условиях градиента температуры на фронте кристаллизации

Ключевые слова: сканирующая жидкофазная эпитаксия; сила Ампера; рост в градиенте температуры.

\section{V.V. Tsybulenko, S.V. Shutov, O.O. Boskin}

\section{THE FEATURES OF SCANNING LIQUID PHASE EPITAXY TECHNIQUE AS APPLIED TO THICK EPITAXIAL LAYERS GROWTH}

Background. Growing of both thin and thick epitaxial layers is an essential part of semiconductor device technology. Liquid phase epitaxy is among well-known technological methods. There are pulse methods of liquid phase epitaxy specially developed for obtaining thin epitaxial layers. Their adaptation or modification for obtaining thick epitaxial layers is an actual issue.

Objective. This work deals with the possibility of obtaining of thick epitaxial layers by extending the capabilities of scanning liquid phase epitaxy technique which also relates to pulse liquid phase growing methods.

Methods. In this work we considered the influence of extra heating of the substrate on the growth of epitaxial layers when using scanning liquid phase epitaxy technique. For this purpose we carried out modelling of heat- and mass transport processes in the apparatus of scanning liquid phase epitaxy in conditions of extra heating of the substrate. To experimentally approve the validity of the model proposed we carried out the growing of Ge epitaxial layer on GaAs substrate in the above mentioned conditions.

Results. The modelling showed that if the substrate was in contact with the solution-melt more than 1 second in conditions of substrate extra heating in scanning liquid phase epitaxy method, a segment of epitaxial layer dissolution appeared in plots of the grown epitaxial layer thickness against the growth time. The crystallization front temperature was lower than the initial solution-melt temperature in this case. We showed that it was connected with the magnitude of initial cooling/heating of the substrate heater. The modelling also showed that the epitaxial layer growth occurred in kind of a temperature gradient due to the extra substrate heating. Thus in a few seconds there took place the growth in the time-constant temperature gradient. Using the extra substrate heating we obtained epitaxial Ge layer on GaAs substrate from Ga-Ge solution-melt. The growth time was $60 \mathrm{sec}$. The layer thickness determined by spherical slice technique was 12.6 um.

Conclusions. In this work we showed that using extra heating of the substrate's back side there appeared the conditions for growing of thick epitaxial layers by scanning liquid phase epitaxy technique in case when the substrate temperature was lower than the solutionmelt temperature. Here the growth of thick epitaxial layers took place in the condition of temperature gradient at crystallization front.

Keywords: scanning liquid phase epitaxy; Ampere force; temperature gradient growth.

Рекомендована Радою

інженерно-фізичного факультету

КПІ ім. Ігоря Сікорського
Надійшла до редакції

04 березня 2020 року

Прийнята до публікації

25 червня 2020 року 